\title{
APLIKASI E-LIBRARY PADA PERPUSTAKAAN PT. PUSRI PALEMBANG BERBASIS WEB MENGGUNAKAN FRAMEWORK CODEIGNITER
}

\author{
Muhammad Fauzan Prasetyo ${ }^{1}$, Qoriani Widayati², \\ ${ }^{1,2}$ Manajemen Informatika,Fakultas Vokasi,Universitas Bina Darma, \\ E-mail: fauzanfsb@gmail.com¹, qoriani_widayati@binadarma.ac.id ${ }^{2}$
}

\begin{abstract}
The problem in this research is how to build an e-library application at PT. Pupuk Sriwidjaja Palembang based on web using codeigniter framework. The purpose of this research is to solve problems in the library system which is less efficient, especially in obtaining information on books in the library and member registration, in addition to the policies of the manager of the education and training (Diklat) office of PT. Pupuk Sriwidjaja Palembang to turn some of the books in the library into e-books. This study uses the waterfall method, often called the classic life cycle (classic life system and software design, implementation and unit testing, integration and system testing and operation and maintenance. Data collection methods are through literature study, interviews and observations. The results of this study make it easier for PT employees to collect data. Pupuk Sriwidjaja in finding information on books that are available for use and can read e-books anywhere and anytime.
\end{abstract}

Keywords: Visual Studio Code, PT. Pupuk Sriwidjaja Palembang, PHP, Framework, Codeigniter

\section{Abstrak}

\begin{abstract}
Masalah dalam penelitian ini adalah bagaimana cara membangun aplikasi e-library pada PT. Pupuk Sriwidjaja Palembang berbasis web menggunakan framework codeigniter. Tujuan penelitian ini adalah untuk mengatasi masalah pada system perpustakaan yang kurang efisien terutama dalam memperoleh informasi buku yang ada diperpustakaan dan pendaftaran anggota, selain itu sesuai kebijakan manajer dinas pendidikan dan pelatihan (Diklat) PT. Pupuk Sriwidjaja Palembang untuk menjadikan sebagian buku diperpustakaan menjadi e-book. Penelitian ini menggunakan metode waterfall sering dinamakan siklus hidup klasik (classic life system and software design, implementation and unit testing, integration and system testing dan operation and maintaince. Metode pengumpulan data melalui studi pustaka, wawancara dan pengamatan. Hasil penelitian ini lebih mempermudah karyawan PT. Pupuk Sriwidjaja dalam mencari informasi buku yang ada diperputakaan dan dapat membaca e-book dimanapun dan kapanpun.
\end{abstract}

Kata Kunci: Visual Studio Code, PT. Pupuk Sriwidjaja Palembang, PHP, Framework, Codeigniter.

\section{Pendahuluan}

E-library merupakan perpustakaan yang mempunyai koleksi buku sebagian besar dalam bentuk format digital dan bisa diakses dengan berbagai device yang ada.Keberadaaan e-library tentunya sangat membantu dalam menunjang aktivitas akademik. PT. Pupuk Sriwidjadja (PUSRI) adalah Badan Usaha Milik Negara (BUMN) yang bergerak dibidang industry pupuk, sebagai pelopor produsen pupuk urea di Indonesia

Saat pada perpustakaan PT. Pupuk Sriwidjadja Palembang (PUSRI) memiliki aplikasi perpustakaan yang dibuat dengan menggunakan php native pada tahun 2004, aplikasi tersebut hanya bisa diakses secara offline. Aplikasi ini dinilai kurang efisien karna terdapat beberapa kendala yaitu pendaftaran anggota perpustakaan masih secara manual, sebab belum tersedianya database yang menyimpan semua data . Kendala lainnya adalah lokasi perpustakaan yang terbilang cukup jauh dari lokasi kerja karyawan 
sehingga menyita banyak waktu untuk datang keperpustakaan karna perpustakaan ini belum bisa diakses secara online. Selain itu, pihak manajemen perpustakan bermaksud memperbarui perpustakaan dengan mengurangi buku yang terdapat di perpustakaan, dengan menjadikan sebagian buku menjadi $e$-book .

Dari permasalahan tersebut penulis tertarik untuk mengangkat menjadi judul penelitian, penulis akan membangun system yang berbasis online guna mempermudah petugas perpustakaan dalam pengolahan data anggota perpustakaan serta mempermudah karyawan dalam aktivitas membaca buku tanpa harus datang keperpustakaan karna perpustakaan akan dapat diakses melalui web yang menyediakan fitur membaca dan mendownload $e$-book bagi anggota.

\section{Landasan Teori}

\subsection{Perpustakaan Digital}

Berdasarkan kutipan dari Wikipedia Bahasa Indonesia (2020) Perpustakaan digital (Inggris: digitallibrary atau electronic library atau virtual library) adalah perpustakaan yang mempunyai koleksi buku sebagian besar dalam bentuk format digital dan yang bisa diakses dengan komputer.

\subsection{PHP}

PHP adalah bahasa skrip yang dapat ditanamkan atau dsisipkan ke dalam HTML. PHPbanyak dipakai untuk membuat situs webdinamis. PHP dapat digunakan untuk membangun sebuah CMS (Content Management System). (Mandala, 2015:24).

\subsection{MySQL}

Menurut MADCOMS (2016) "MySQL adalah sistem manajemen Database SQL yang bersifat Open Source dan paling popular saat ini. Sistem Database MySQL mendukung beberapa fitur seperti multithreaded, multiuser dan SQL Database managemen system (DBMS)".

\subsection{Framework Codeigniter}

Menurut Badiyanto dan Yosef Murya (2018) pada bukunya yang berjudul Project PHP Sistem Informasi dengan Framework Codeigniter, framework secara sederhana dapat diartikan sebagai kumpulan dari fungsi atau prosedur dan class untuk tujuan tertentu yang sudah siap untuk digunakan.

\section{Metodologi Penelitian}

\subsection{Waktu dan Tempat Penelitian}

Penelitian dilakukan di PT.Pusri Palembang yang berlokasi di Jl. Mayor Zen Kalidoni Palembang, Penelitian ini dilaksanakan pada 20 Januari 2020 sampai 20 April 2020.

\subsection{Metode Pengumpulan Data}

Metode Pengumpulan data yang digunakan diatantaranya adalah sebagai berikut:

1. Wawancara, Wawancara dilakukan dengan petugas perpustakaan pada PT.Pusri Palembang terkait dengan masalah yang ada diperpustakaan. Hal ini untuk memperoleh informasi tentang data perpustakaan.

2. Metode Obervasi, Pada metode ini penulis melakukan pengumpulan data secara langsung demi mendapatkan informasi seputar perpustakaan pada PT.Pusri Palembang dengan cara melihat data kegiatan-kegiatan yang ada untuk menjadi pembahasan tugas akhir nanti.

3. Metode Pustaka, Dalam metode studi pustaka,penulis mencari bahan - bahan yang mendukung dalam penyelesaian masalah melalui buku, internet, dan media informasi lainnya yang berkaitan erat dengan objek permasalahan. 


\subsection{Metode Pengembangan Sistem}

Bagian ini akan menjelaskan mengenai tahapan dalam penelitian. Alur penelitian yang dilakukan adalah sebagai berikut

1. Analisis kebutuhan perangkat lunak, Proses pengumpulan data kebutuhan dilakukan secara intensif untuk menspesifikasikan kebutuhan perangkat lunak agar dapat dipahami perangkat lunak seperti apa yang di butuhkan oleh user.

a. Wawancara, Wawancara dilakukan dengan petugas perpustakaan pada PT.Pusri Palembang terkait dengan masalah yang ada diperpustakaan.

b. Metode Obervasi, Pada metode ini penulis melakukan pengumpulan data secara langsung demi mendapatkan informasi seputar perpustakaan pada PT.Pusri Palembang dengan cara melihat data kegiatan-kegiatan yang ada.

c. Metode Pustaka, Penulis mencari bahan - bahan yang mendukung dalam penyelesaian masalah melalui buku, internet, dan media informasi lainnya yang berkaitan erat dengan objek permasalahan.

2. Desain, Desain perangkat lunak adalah proses multi langkah yang fokus pada desain pembuatan program perangkat lunak termasuk struktur data, arsitektur perangkat lunak, reprentasi antarmuka, dan prosedur pengodean.

3. Pembuatan Kode Program, Desain harus ditranslasikan ke dalam program perangkat lunak. Hasil dari tahap ini adalah program komputer sesuai dengan desain yang telah dibuat pada tahap desain.

4. Pengujian, Pengujian fokus pada perangkat lunak secara dari fungsi lojik dan fungsional dan memastikan bahwa semua bagian sudah diuji.

\section{Hasil dan Pembahasan}

\subsection{Analisis Sistem}

Pada tahapan ini dimulai dengan membangun syarat dari semua elemen siste yang dibutuhkan dalam membuat aplikasi elibrary berbasis web pada perpustakaan PT. Pupuk Sriwidjaja Palembang (PUSRI) menggunakan komputer berbasis Windows yang memiliki perangkat keras maupun perangkat lunak kebutuhan perangkat dapat dilihat pda table dibawah ini:

Tabel 1 Perangkat keras yang dibutuhkan

\begin{tabular}{ccc}
\hline No & Perangkat Keras & Spesifikasi \\
\hline 1 & Laptop & Acer \\
2 & Processor & Intel Core i3 \\
3 & Mouse & 3200 DPI \\
4 & Printer & Canon iP 2770 \\
\hline
\end{tabular}

Tabel 2 Perangkat lunak yang dibutuhkan

\begin{tabular}{ccc}
\hline No & Perangkat Lunak & Versi \\
\hline 1 & Sistem Operasi Windows & Windows 8 Pro \\
2 & Xampp & 7.1 .32 \\
3 & Visual Studio Code & 1.46 .1 \\
4 & Microsoft Word & 2010 \\
5 & Google Chrome & 84.0 .4147 .89 \\
6 & StarUML & 2.8 .1 \\
\hline
\end{tabular}

\subsection{Perancangan Sistem}

Peracangan sistem merupakan tahap selanjutnya setelah melakukan analisa sistem, mendapatkan gambaran dengan jelas tentang apa yang di kerjakan pada analisa sistem, maka dilanjutkan dengan pemimikiran bagaiman membuat sistem tersebut. 


\section{a. Use Case Diagram}

Berikut adalah Use case diagaram Aplikasi elibrary berbasis web pada perpustakaan PT. Pupuk Sriwidjaja Palembang (PUSRI).

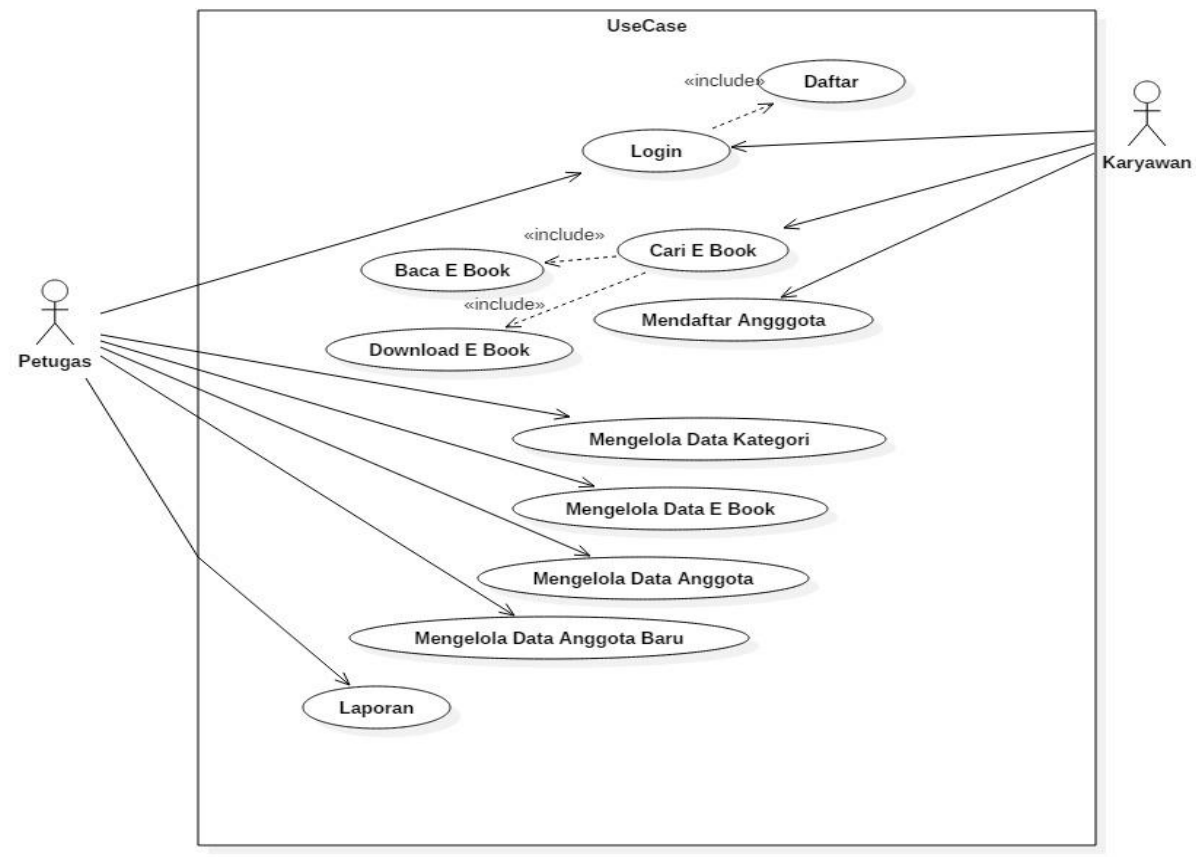

Gambar 1. Use Case Diagram

\section{b. Activity Diagram}

Pada Activity diagram ini mengambarkan aktivitas pengguna berinteraksi dengan Aplikasi elibrary Berbasis Web pada PT. Pupuk Sriwidjaja Palembang (PUSRI).

1. Activity diagram petugas, Activity diagram petugas menggambarkan aliran kerja sisitem terhadap user petugas:

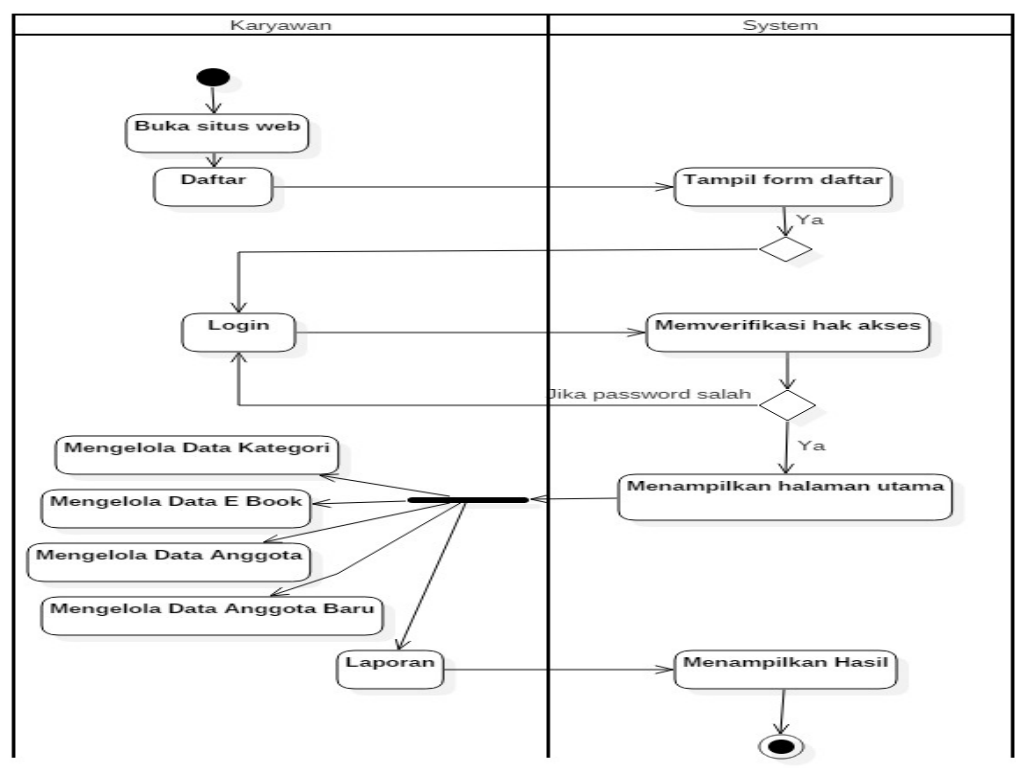

Gambar 2. Activity Diagram Petugas 
2. Activiy diagram karyawan, Activity diagram karyawan adalah aliran kerja sistem terhadap karyawan, berikut adalah activity diagramnya:

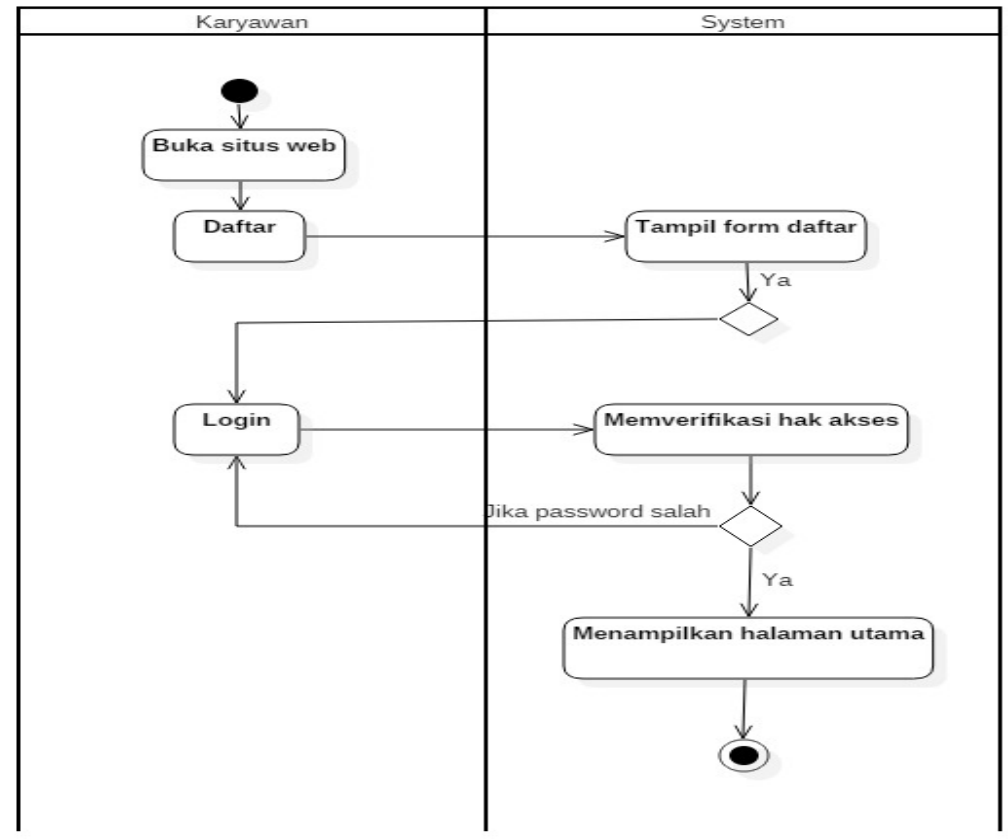

Gambar 3. Activity Diagram Karyawan

\section{c. Class Diagram}

Class diagram menjelaskan objek yang saling berkaitan. Berikut adalah Class diagram Aplikasi elibrary berbasis web pada perpustakaan PT. Pupuk Sriwidjaja Palembang (PUSRI).

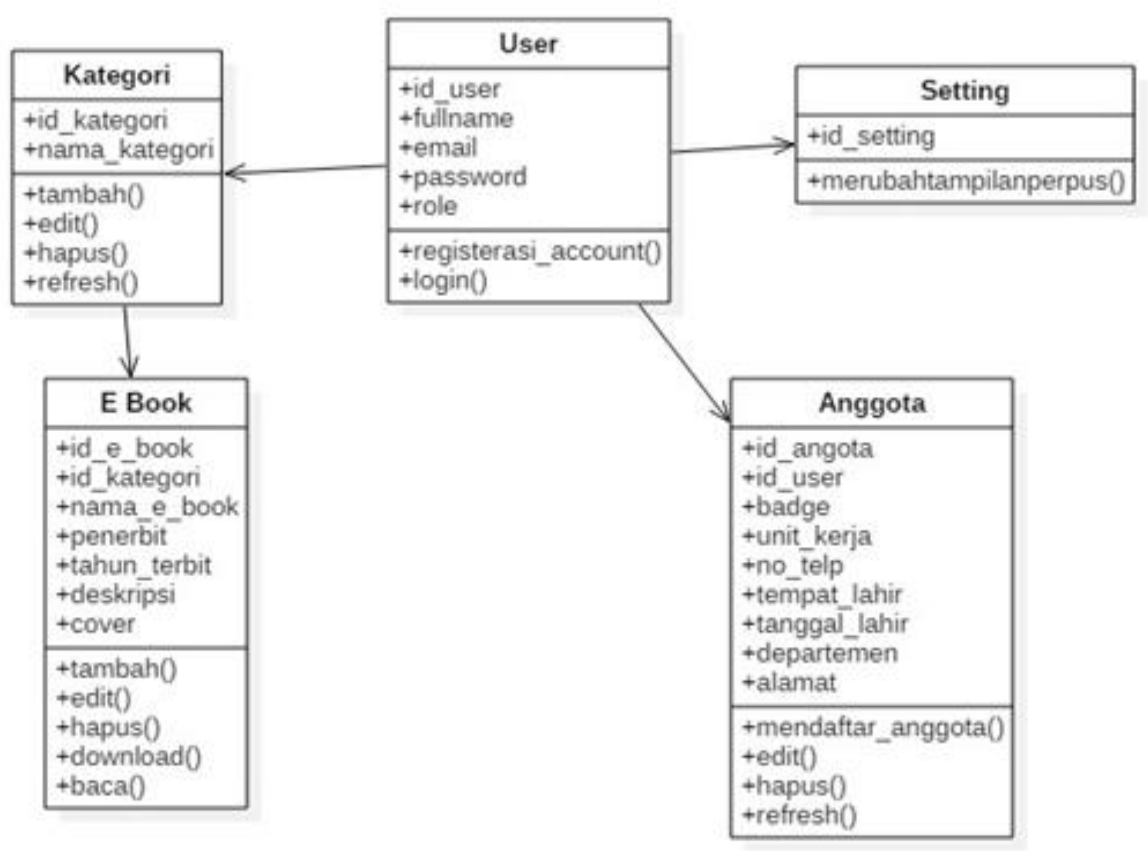

Gambar 4. Class Diagram 


\subsection{Pembahasan}

Berikut merupakan beberapa tampilan hasil aplikasi yang telah dibangun: Halaman dibawah ini akan tampil ketika user yang mengetikan alamat dari aplikasi yang telah hasilkan, maka akan muncul halaman dari aplikasi e-library berbasis web

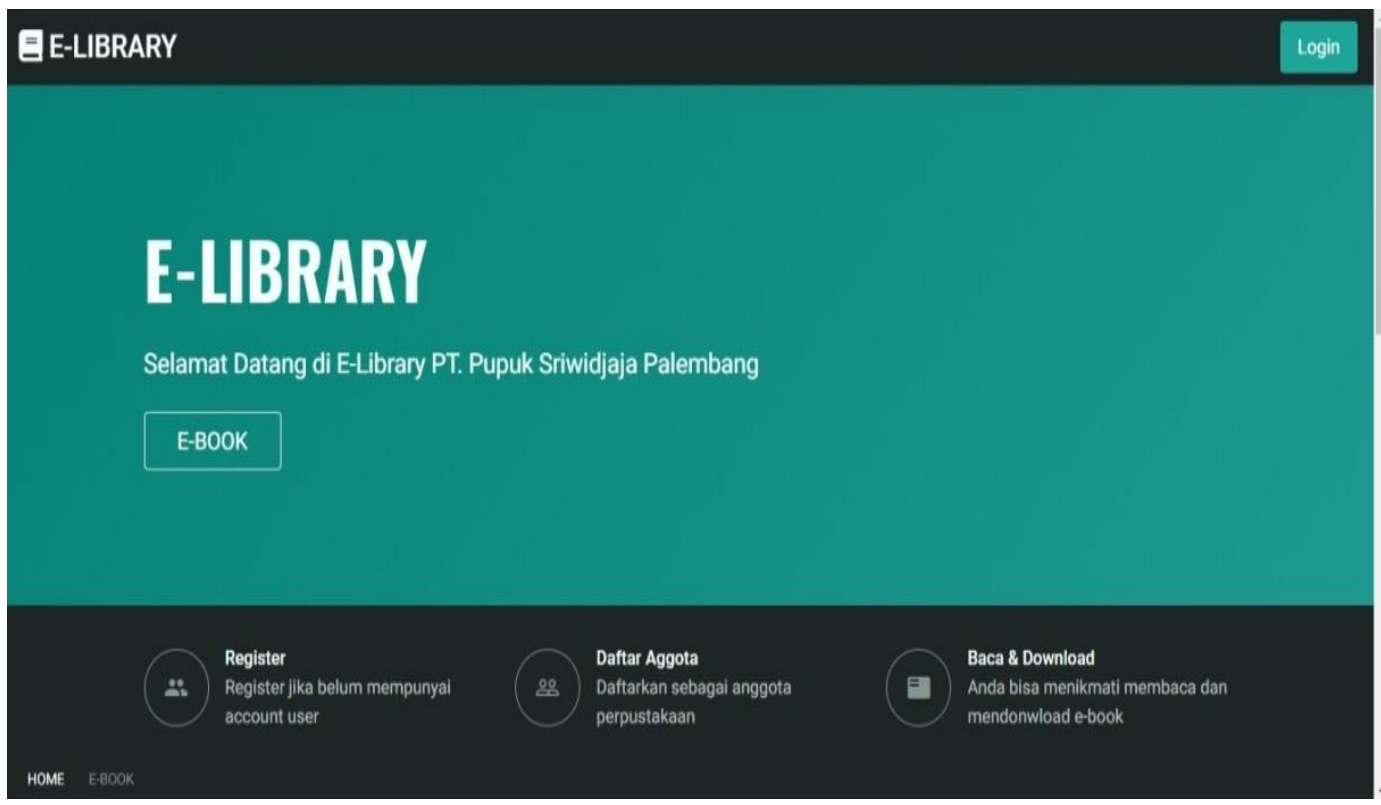

Gambar 5. Tampilan Halaman User

Halaman $e$-book user adalah halaman yang digunakan user untuk membaca dan mendownload $e$-book yang ada pada aplikasi apabila sudah terdaftar menjadi anggota

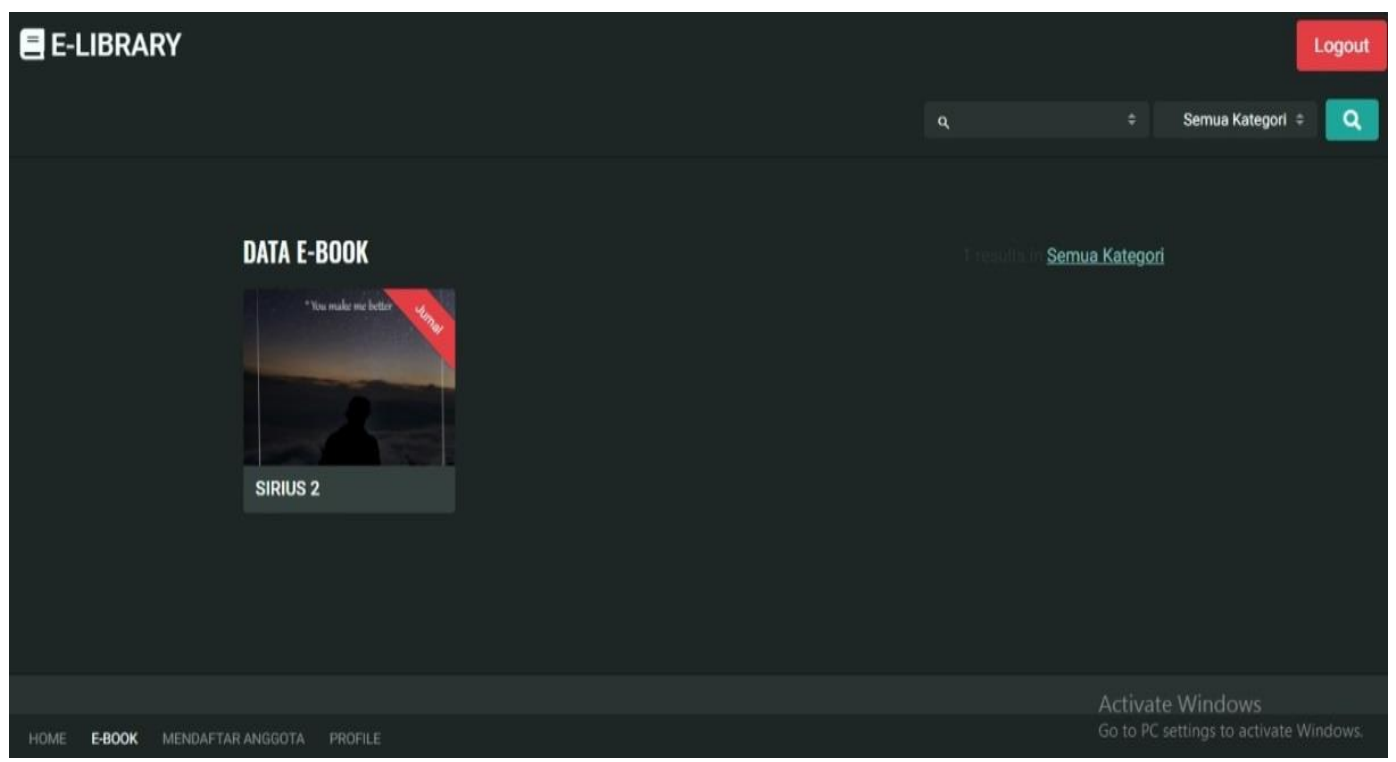

Gambar 6. Tampilan Halaman E-Book User

Halaman dashboard admin adalah pusat control panel yang berfungsi untuk mengatur semua kegiatan disebuah situs atau website. 


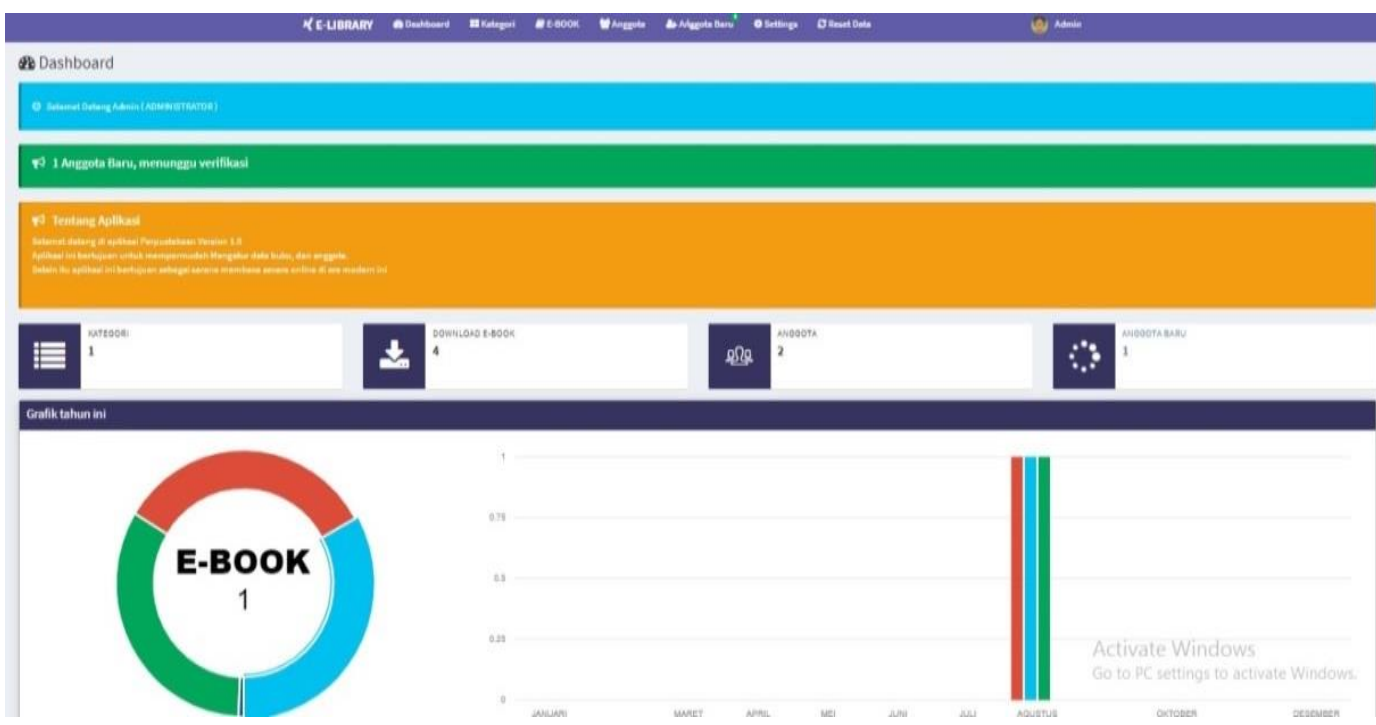

Gambar 7. Tampilan Halaman Dashboard Admin

Halaman kategori digunakan admin untuk mengelola data kategori buku dan kategori e-book pada aplikasi $e$-library.

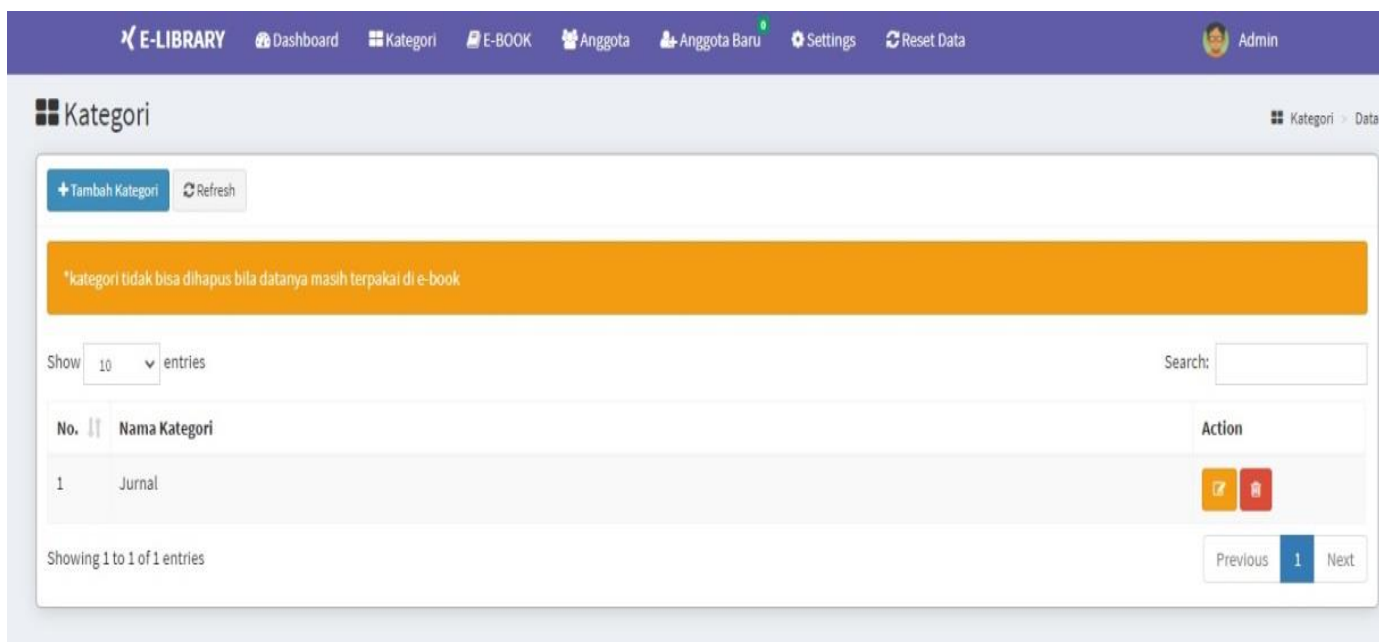

Gambar 4.8 Tampilan Halaman Kategori

\section{Kesimpulan}

Penelitian ini menghasilkan sebuah Aplikasi E-Library menggunakan Framework Codeigniter yang dapat diakses online melalui web. Dengan adanya aplikasi ini dapat memudahkan anggota perpustakaan maupun karyawan untuk mengakses perpustakaan secara online. Aplikasi ini dapat lebih baik lagi dikemudian hari dengan mengembangkan ataupun membuat beberapa fitur lagi yang lebih bermanfaat.

\section{Daftrar Pustaka}

[1] Badiyanto dan Yosef Murya. 2018. Project PHP : Membangun Sistem Informasi

[2] Akademik Dengan Framework Codeigniter, Yogyakarta: Cv. Langit Inspirasi https://id.wikipedia.org/wiki/Perpustakaan_digital....Diakses...15/07/ 
[3] Atningsih, Suria., \& Sugiarto, Hari. 2017. Perancangan Sistem Informasi Perpustakaan Digital Berbasis Web. Indonesian Journal on Networking and Security. 6(4): 44-48.

[4] Ayu, Fitri., \& Permatasari, Nia. 2018. Perancangan Sistem Informasi Pengolahan Data Praktek Kerja Lapangan (PKL) Pada Devisi Humas PT. Pegadaian. Jurnal Intra-Tech. 2(2): 12-26.

[5] Ayu, Fitri., \& Sholeha, Wahyuni. 2019. Rancang Bangun Sistem Informasi Penjadwalan Mata Pelajaran Berbasis Web Pada Smart Center Pekanbaru. Jurnal Intra-Tech. 3(1): 38-48.

[6] Bahri, Ghozi. 2019. Perancangan dan Implementasi Sistem Manajemen Peminjaman Mobil dengan Metode Scrum di Universitas Internasional Batam. Skripsi Tidak Diterbitkan. Batam. Universitas Internasional Batam.

[7] Destiningrum, Mara., \& Adrian, Qadhli Jafar. 2017. Sistem Informasi Penjadwalan Dokter Berbasis Web Dengan Menggunakan Framework Codeigniter ( Studi Kasus: Rumah Sakit Yukum Medical Centre ). Jurnal TEKNOINFO. 11(2): 30-37.

[8] Ningsih, Wahyu Tia., Yunus, Yuliawati., \& Radyuli, Popi. P. 2020. Perancangan dan Pembuatan Sistem Informasi Perpustakaan Berbasis Web dengan PHP dan MySQL ( Studi Kasus SMK Negeri 7 Padang ). Jurnal Pendidikan Teknologi Informasi. 7(1): 60-69.

[9] Yudha, Aditya Putra., \& Sinatra, Yanuar. 2016. Perancangan dan Implementasi Aplikasi Perpustakaan Berbasis Web Dengan SMS Gateway Menggunakan Metode Waterfall Di SMP Negeri 2 Singosari. Skripsi Tidak Diterbitkan. Malang. Sekolah Tinggi Tenik Malang. 